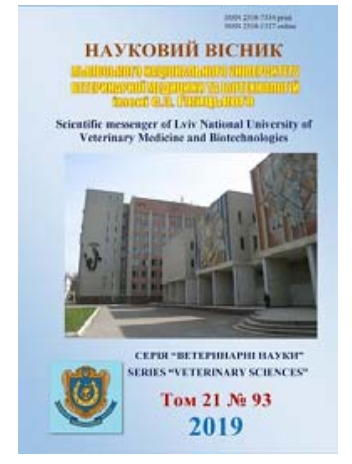

Науковий вісник Дьвівського національного університету ветеринарної медицини та біотехнологій імені С.3. Гжицького.

\author{
Серія: Ветеринарні науки
}

Scientific Messenger of Lviv National University of Veterinary Medicine and Biotechnologies. Series: Veterinary sciences

UDC 619: 612.111: 616.992.28: 636.8

\title{
Changes of hematological parameters of in blood in cats ill with microsporium
}

\author{
Yu.V. Martyniv, Ia.V. Kisera \\ Stepan Gzhytskyi National University of Veterinary Medicine and Biotechnologies Lviv, Ukraine
}

Article info

Received 24.01.2019

Received in revised form 06.03 .2019

Accepted 07.03.2019

Stepan Gzhytskyi National University of Veterinary Medicine and Biotechnologies Lviv, Pekarska Str., 50, Lviv, 79010, Ukraine.

Tel.: +38-097-155-47-53

E-mail:julia_yush@ukr.net

Martyniv, Yu.V., \& Kisera, Ia.V. (2019). Changes of hematological parameters of in blood in cats ill with microsporium. Scientific Messenger of Lviv National University of Veterinary Medicine and Biotechnologies. Series: Veterinary sciences, 21(93), 70-73. doi: 10.32718/nvlvet 9313

There has been a massive tendency for cats to be kept as pets in Ukraine in recent years. The frequency of their diseases has also increased at the same time. Cats most often come into the homes of people from the street, from volunteers, rarely from nurseries. Due to this, Doctors often receive cats ill for microsporia, which is caused by fungi of the genus Microsporum and is one of the most common anthropozoonous diseases. The treatment process is carried out by a complex method. Analysis of the recommendations of various authors on the treatment of microsporia indicates the lack of immunostimulants in the conduct of a complex of therapeutic and preventive measures. Hematological studies were performed in order to find out the immune reactivity of the cats' organism during microsporia. The research was conducted on clinically healthy and cats ill for microspores. The obtained results of research showed that in cats with microsporia changes in morphological composition of blood were characterized by signs of anemia, leukopenia and lymphocytopenia. Changes in the structure of neutrophils were found in the type of vacuum and toxigenic grains in cats ill for microsporia. The toxic grains of neutrophils occur inside the cell as a result of physicochemical changes in the protein structure of the cytoplasm. Such cells can not provide phagocytosis of foreign agents and thus reduce the immune activity of the organism in cats ill for microsporium. A marked change in the shape of erythrocytes, which is characteristic of anemia, that is, erythrocytes-octantocytes with corneas by Jolly inclusions. Jolly's bodies are the remnants of the nucleus that have survived in erythrocytes because of the broken destruction of the normoblast nucleus. The obtained results indicate that the course and manifestation of microsporia in cats affects the immune status of the organism.

Key words: cat, microsporia, immunity, blood, leukocytes, lymphocytes, neutrophils, red blood cells, anemia.

\section{Зміни гематологічних показників крові у хворих на мікроспорію котів}

\author{
Ю.В. Мартинів, Я.В. Кісера
}

Львівський національний університет ветеринарної медицини та біотехнологій імені С. З. Гжицького, м. Львів, Україна

За останні роки в Украӥні спостерігається масова тенденція до утримання котів. Водночас зросла і частота їх захворювань. Коти найчастіше потрапляють в домівки людей з вулиці, від волонтерів, рідко з розплідників. Через це, часто на прийом до лікаря приводять хворих котів на мікроспорію, яка викликається грибками роду Містоsротит і належить до одного з найпоширеніших антропозоонозних захворювань. Лікування проводиться комплексним методом. Аналіз рекомендацій різних авторів по лікуванні мікроспорії вказує на відсутність імуностимулюючих препаратів при проведенні комплексу лікувально-профілактичних заходів. 3 метою з'ясування імунної реактивності організму котів при мікроспорії проведені гематологічні дослідження. Дослідження проведені на клінічно здорових і хворих мікроспорією котах. Одержані результати досліджень засвідчили, у хворих на мікроспорію котів зміни морфологічного складу крові, які характеризувались ознаками анемї, лейкопенії та лімфоцитопенії. У хворих на мікроспорію котів виявлені зміни в структурі нейтрофілів за типом вакуолізації та токсигенної зернистості. Токсигенна зернистість нейтрофілів відбувається всередині клітини в результаті фізико-хімічних змін білкової структури циитоплазми. Такі клітини не 
можуть забезпечити фагоцитоз чужсорідних агентів і таким чином знижується імунна активність організму у хворих на мікроспорію котів. Відмічена зміна форми еритроцитів, яка характерна при анемї, тобто еритроцити-окантоцити з тільцями включеннями Жоллі. Тільия Жоллі - залишки ядра, які збереглися в еритрочитах через порушене руйнування ядра нормобластів. Одержані результати вказують, що на перебіг і прояв мікроспорї у котів впливає імунний статус організму.

Ключові слова: кіт, мікроспорія, імунітет, кров, лейкоцити, лімфоцити, нейтрофіли, еритроцити, анемія.

Вступ

У повсякденній ветеринарній практиці одними 3 найбільш неприємних захворювань є грибкові та їх різновиди, оскільки в багатьох випадках вони порівняно важко піддаються лікуванню, а також є небезпечними для людини (Mejer \& Harvi, 2007; Bezlushhenko, 2017). До таких належить мікроспорія у котів.

Збудником мікроспорії є гриб Microsporum canis роду Microsporum з групи Dermatophytes (Yu et al., 2004; Moriello et al., 2017). Стійкі в зовнішньому середовищі і можуть зберігати свою вірулентність в ураженому волоссі упродовж 5-10 років. У грунті зберігаються до 3 місяців (da Costa et al., 2013).

Мікроспорія у котів протікає зазвичай у поверхневій формі й характеризується випаданням і обламуванням ураженого волосу 3 утворенням на їх місці локальних, різко обмежених безволосих ділянок шкіри (Chermette et al., 2008; Di Mattia et al., 2019). Останні зазвичай сухі, без ознак ексудації. Уражені вогнища можуть бути поодинокими або розташовуватися на різних ділянках тіла тварини (Kurasova et al., 1971; Golovina, 1988; Peterson, 2008).

Хворобу діагностують на підставі характерних клінічних ознак і епізоотологічних даних. Точний діагноз мікроспорії можна встановити тільки за результатами лабораторних досліджень. Для експрес діагностики мікроспорії застосовують ртутнокварцові лампи (лампа 'Вуда'). При цьому уражені ділянки дають яскраво-зелене, смарагдове світіння в ультрафіолетових променях.

При мікроспорії практикуючі лікарі ветеринарної медицини дотримуються системної та місцевої протигрибкової терапії. Насамперед хворих ізолюють. Місцева терапія включає нанесення на ушкоджені ділянки шкіри протигрибкових препаратів або купання протигрибковими шампунями 3 хлоргексидином, міконазолом, кетоконазолом, клотримазолом, гіпохлоритом натрію та повідон-йодом. Для системної терапії рекомендовані протигрибкові препарати гризеофульвін, кетоконазол, ітраконазол. Розроблена протигрибкова вакцина Fel-O-Vax MC-K, Fort Dodgel (Kirk \& Bonahura, 2014).

Аналіз рекомендацій різних авторів щодо лікування мікроспорії вказує на відсутність імуностимулюючих препаратів при проведенні комплексу лікувальнопрофілактичних заходів. Одним з головних факторів у розвитку мікроспорії є зниження імунної реактивності організму (Spesivceva, 1960; Tutel'jan \& Kravchenko, 1985).

Мета дослідження - дослідити закономірність змін картини крові у хворих на мікроспорію котів.

\section{Матеріал і методи досліджень}

Робота виконувалась в умовах приватної ветеринарної клініки "Імпульс" м. Львова упродовж 2018 року. Було сформовано 1-у контрольну та 1-у дослідну групи, по 9 котів у кожній. Контрольна група - клінічно здорові коти, дослідна група - коти хворі на мікроспорію.

Кількість еритроцитів і лейкоцитів визначали шляхом їх підрахунку в камері Горяєва (Kondrahin et al., 2004), вміст гемоглобіну гемоглобінціанідним методом (Vlizlo et al., 2014).

Лейкограму виводили на основі підрахунку та диференціації 200 клітин лейкоцитів у мазках крові, пофарбованих за методикою Романовського-Гімзи. При цьому враховували розмір клітин, величина i форма ядра, наявність та колір зерен у цитоплазмі (Karput, 1986).

Гематокритну величину визначали за допомогою гематокритних капілярів шляхом їхнього центрифугування у спеціальній центрифузі (10 хвилин при 3000 обертів за хвилину), швидкість осідання еритроцитів (протягом 1 години) - 3 допомогою піпеток Панченкова (Kozinca \& Makarova, 1997).

Цифровий матеріал статистично опрацьовували за допомогою комп'ютерної програми Excel 3 пакету "Microsoft Office 2007". Вірогідність визначали за t критерієм.

\section{Результати та їх обговорення}

Проведенні гематологічні дослідження показали, що у тварин дослідної групи характерними $є$ зміни морфологічного складу крові (табл. 1). У хворих тварин відзначили ознаки анемії, лейкопенії, лімфоцитопенії. Зокрема, виявлено зниження кількості еритроцитів до 5,7 $\pm 0,28 \mathrm{~T} / л$, при $8,17 \pm 0,24 \mathrm{~T} / л$ у тварин контрольної групи. Рівень гемоглобіну у крові тварин дослідної групи був нижчий на 75,11 г/л (P < 0,001), ніж у контролі. Це вказує на зміни насиченості еритроцитів гемоглобіном. Кількість лейкоцитів вірогідно знижується до $3,93 \pm 0,42$ Г/л з $10,47 \pm 0,33$ Г/л у тварин контрольної групи. Вміст лімфоцитів знижується 3 33,44 $\pm 1,58$ до 20,55 $\pm 1,77 \%$ у тварин дослідної групи (Р $<0,01)$. У тварин дослідної групи встановлено вірогідне підвищення вмісту у крові паличкоядерних нейтрофілів та еозинофілів.

Відомо, що лейкоцити в організмі тварин відіграють захисну, трофічну і транспортуючу функції. Захисна функція лейкоцитів - забезпечення клітинного імунітету. Вони розпізнають і знешкоджують генетично чужорідні мікроорганізми (противірусний та протибактеріальний захист). Також знищують клітини, 
що руйнуються та перероджені клітини власного організму, розпізнають і знешкоджують генетично чужорідні речовини, що потрапляють в організм. Нейтрофільні гранулоцити один з видів лейкоцитів із гранулами всередині цитоплазми. Нейтрофіли беруть участь у захисних функціях організму. Вони містять лізосомні ферменти і головна їх функція - фагоцитоз. Нейтрофіли мають здатність активно пересуватися в тканинах до вогнища запалення і фагоцитувати мікроорганізми та інші дрібні частинки (Khariv \& Hutyi, 2017; Kysera et al., 2018).

\section{Таблиця 1}

Морфологічні показники крові у котів хворих мікроспорією $(\mathrm{M} \pm \mathrm{m}, \mathrm{n}=9)$

\begin{tabular}{|c|c|c|c|}
\hline Показники & $\begin{array}{c}\text { Одиниці } \\
\text { виміру }\end{array}$ & $\begin{array}{c}\text { Контрольна } \\
\text { група } \\
\end{array}$ & $\begin{array}{c}\text { Дослідна } \\
\text { група }\end{array}$ \\
\hline Еритроцити & Т/л & $8,17 \pm 0,24$ & $5,7 \pm 0,28$ \\
\hline Гемоглобін & г/л & $172 \pm 5,28$ & $96,89 \pm 5,83^{* * *}$ \\
\hline $\begin{array}{l}\text { Гематокритна } \\
\text { величина }\end{array}$ & $\%$ & $37,67 \pm 1,83$ & $37,26 \pm 2,44$ \\
\hline Тромбоцити & Г/л & \multicolumn{2}{|c|}{$315 \pm 17,88292,11 \pm 28,53$} \\
\hline Лейкоцити & Г/л & $10,47 \pm 0,33$ & $3,93 \pm 0,42 * * *$ \\
\hline Нейтрофіли & $\begin{array}{l}\% \\
\%\end{array}$ & $\begin{array}{r}2,89 \pm 0,42 \\
58,22 \pm 1,58\end{array}$ & $\begin{array}{l}6,89 \pm 0,73 * * * \\
64,0 \pm 1,52\end{array}$ \\
\hline Еозинофіли & $\%$ & $2,78 \pm 0,46$ & $4,56 \pm 0,75^{* *}$ \\
\hline Базофіли & $\%$ & 0 & 0 \\
\hline Моноцити & $\%$ & $2,67 \pm 0,37$ & $2,0 \pm 0,27$ \\
\hline Лімфоцити & $\%$ & $33,44 \pm 1,58$ & $20,55 \pm 1,77 * *$ \\
\hline ШOE & мм/год & $2,56 \pm 0,9$ & $1,89 \pm 0,31$ \\
\hline $\begin{array}{l}\text { Кольоровий } \\
\text { показник }\end{array}$ & & $0,84 \pm 0,03$ & $0,58 \pm 0,02$ \\
\hline
\end{tabular}

Примітка: вірогідність різниць 3 клінічно здоровими тваринами: ** - при $\mathrm{P}<0,01 ; * * *$ - при $\mathrm{P}<0,001$.

Лімфоцитопенія в поєднанні з лейкопенією свідчить про виснаження захисних сил організму.

У тварин дослідної групи виявлені зміни в структурі нейтрофілів за типом вакуолізації (рис. 1) та токсичної зернистості (рис. 2). Вакуолізація нейтрофілів вказує на виражену нейтрофільну токсичність.

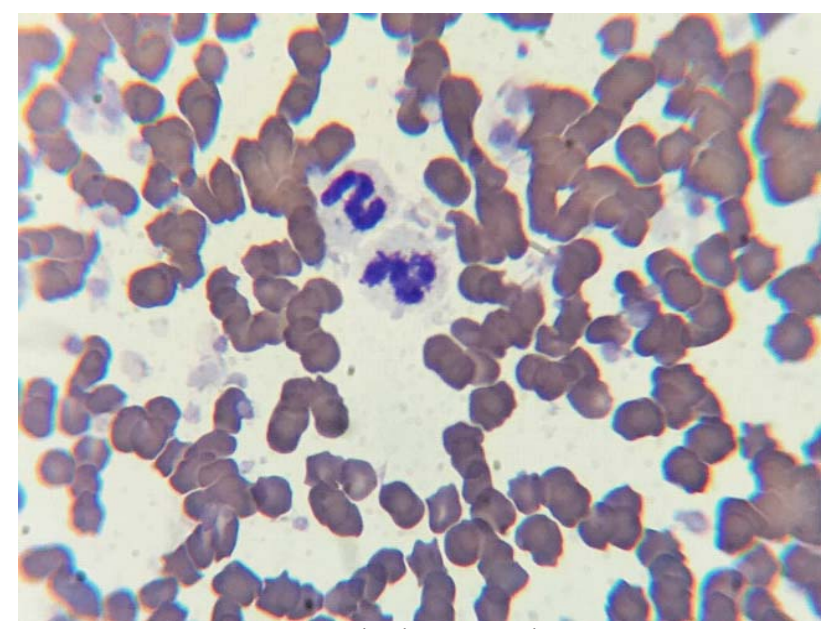

Рис. 1. Хворі мікроспорією коти. Вакуолізація нейтрофілів
Основними причинами появи гігантських нейтрофілів у котів можуть бути інфекції різної етіології та імунодефіцитний стан. Токсигенна зернистість нейтрофілів відбувається всередині клітини в результаті фізико-хімічних змін білкової структури цитоплазми (Mejer \& Harvi, 2007). Такі клітини не можуть забезпечити фагоцитоз чужорідних агентів, і таким чином знижується імунна активність організму у хворих на мікроспорію котів.

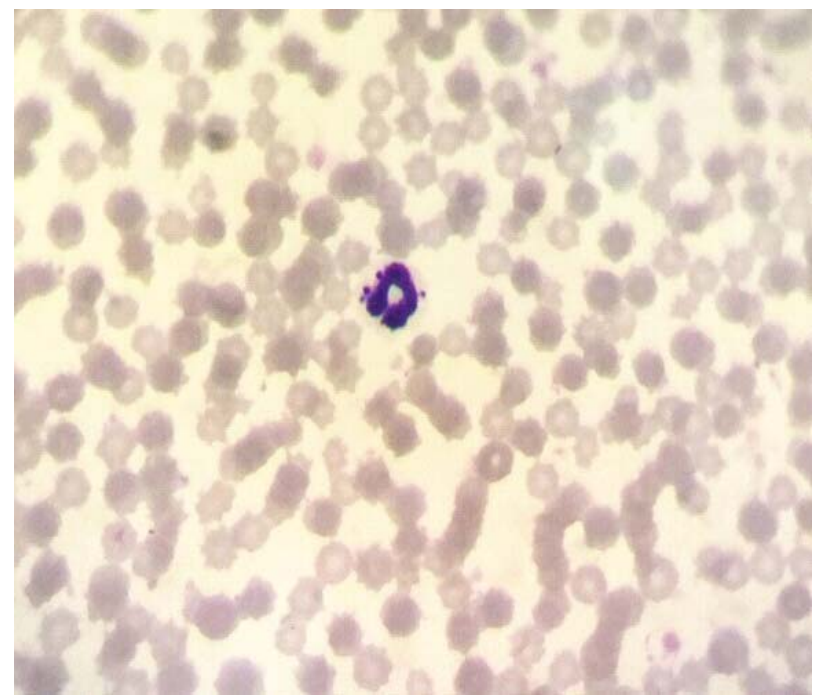

Рис 2. Хворі на мікроспорію коти. Зернистість нейтрофілів

Виявлена зміна форми еритроцитів у вигляді еритроцитів-окантоцитів 3 тільцями включеннями Жолі, яка характерна при анемії (рис 3). Тільця Жоллі залишки ядра, які збереглися в еритроцитах внаслідок порушення процесу змін ядра нормобластів (Mazurkevych, 2012).

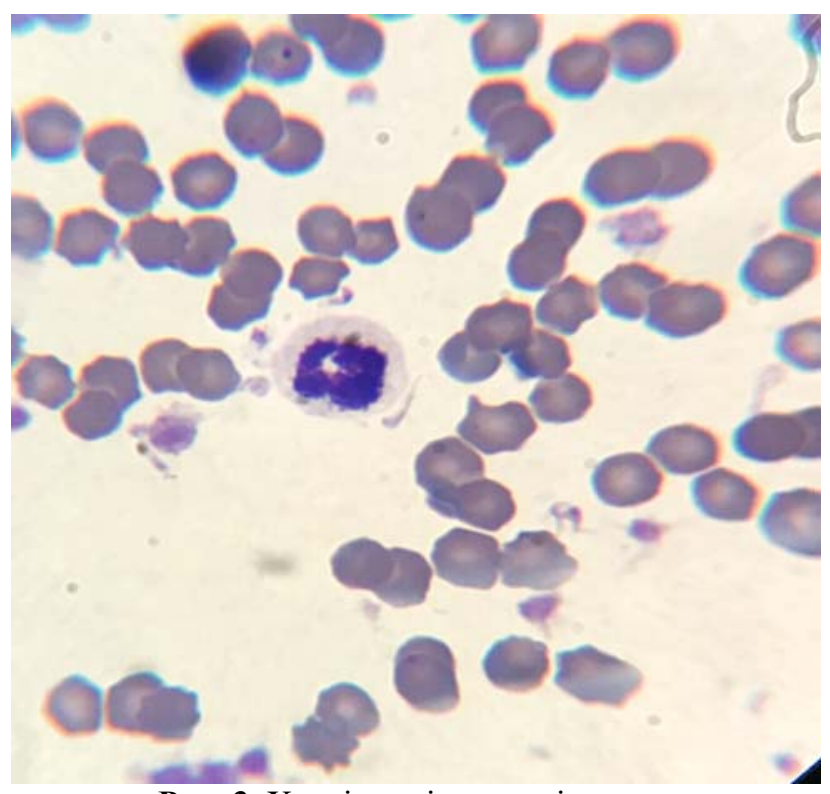

Рис. 3. Хворі на мікроспорію коти.

Еритроцити-окантоцити з тільцями включеннями Жолі 
Одержані результати узгоджуються з даними літератури (Mejer \& Harvi, 2007; Mazurkevych, 2012) i вказують, що на перебіг і прояв мікроспорії у котів впливає імунний статус організму.

\section{Висновки}

1. Вакуолізація та токсична зернистість нейтрофілів вказують на імуносупресивний стан організму.

2. Наявність еритроцитів-окантоцитів 3 тільцями включеннями Жолі свідчать про анемічний стан.

3. Виникнення мікроспорії у котів залежить від резистентності імунної системи організму.

Перспективи подальших досліджень полягають у розробці антисептичного засобу для місцевих обробок "Мікромар" та імуномодулятора "Біоглюк". Антисептичний засіб "Мікромар” на основі повідон-йоду та клотримазолу. Імуномодулятор “Біоглюк” буде включати комбінацію бета-глюкану і біотину.

\section{References}

Bezlushhenko, O.V. (2017). Mikrosporija u koshek. Mir veterinarii, 5, 26-28 (in Russian).

Chermette, R., Ferreiro, L., \& Guillot, J. (2008). Dermatophytoses in animals. Mycopathologia, 166(56), 385-405. doi: 10.1007/s11046-008-9102-7.

da Costa, F.V., Farias, M.R., Bier, D., de Andrade, C.P., de Castro, L.A., da Silva, S.C., \& Ferreiro, L. (2013). Genetic variability in Microsporum canis isolated from cats, dogs and humans in Brazil. Mycoses, 56(5), 582-588. doi: 10.1111/myc.12078.

Di Mattia, D., Fondati, A., Monaco, M., Pasquetti, M., \& Peano, A. (2019). Comparison of two inoculation methods for Microsporum canisculture using the toothbrush sampling technique. Vet Dermatol, 30, 60e17. doi: 10.1111/vde.12705.

Golovina, N.P. (1988). Dermatomikozy sobak i koshek v uslovijah gorodov. Veterinarija, 1, 59-61 (in Russian).

Karput, I.M. (1986). Gematologicheskij atlas sel'skohozjajstvennyh zhivotnyh. Minsk: Uradzhaj (in Russian).

Kirk, R., \& Bonahura, Dzh. (2014). Suchasnyi kurs veterynarnoi medytsyny. Moskva. Akvarium Prynt (in Ukrainian).
Kondrahin, I.P., Arhipov, A.V., \& Levchenko, V.I. (2004). Metody veterinarnoj klinicheskoj laboratornoj diagnostiki: Spravochnik. M. Kolos (in Russian).

Kozinca, G.I., \& Makarova, V.A. (1997). Issledovani sistemy krovi v klinicheskoj praktike. pod red. M. Triada-H (in Russian).

Kurasova, V.V., Kostin, V.V., \& Malinovskaja, L.S. (1971). Metody issledovanija V veterinarnoj mikologii. M. Kolos (in Russian).

Kysera, Ya.V., Storchak, Yu.G., \& Gutyj, B.V. (2018). Experimental study of immunoprophylactic antipneumococcal medicine and its immunogenic properties. Ukrainian Journal of Ecology, 8(1), 307-316. doi: 10.15421/2018_216.

Khariv, M.I. \& Hutyi, B.V. (2017). Dynamika fahotsytarnoi aktyvnosti neitrofiliv u shchuriv za umov oksydatsiinoho stresu ta dii liposomalnoho preparatu. Biolohiia tvaryn, 19(1), 119-124. doi: 10.15407/animbiol19.01.119 (in Ukrainian).

Mazurkevych, A.I. (2012). Fiziolohiia tvaryn. Kyiv: Nova knyha (in Ukrainian).

Mejer, D. \& Harvi, D. (2007). Veterinarnaja laboratornaja medicina. Interpretacija i diagnostika. Moskva: Sofion (in Russian).

Moriello, K.A., Coyner, K., Paterson, S., \& Mignon, B. (2017). Diagnosis and treatment of dermatophytosis in dogs and cats: Clinical Consensus Guidelines of the World Association for Veterinary Dermatology. Vet Dermatol, 28(3), 266-e68. doi: 10.1111/vde.12440.

Peterson, S. (2008). Shkirni khvoroby kotiv. Moskva: Akvarium-Prynt (in Ukrainian).

Pototskyi, M.K. (2000). Dermatomikozy. Veterynarna medytsyna Ukrainy, 11, 20 (in Ukrainian).

Spesivceva, N.A. (1960). Mikozy i mikotoksikozy zhivotnyh. M. Sel'hozizdat (in Russian).

Tutel'jan, V.A., \& Kravchenko, L.V. (1985). Mikotoksiny. M. (in Russian).

Vlizlo, V.V., Slivinska, L.H., Maksymovych, I.A., Leno, M.I., \& Halias, V.L. (2014). Laboratorna diahnostyka u veterynarnii medytsyni. Dovidnyk. 2-he vydannia. Lviv (in Ukrainian).

Yu, J., Wan, Z., Chen, W., Wang, W., \& Li, R. (2004). Molecular typing study of the Microsporum canis strains isolated from an outbreak of tinea capitis in a school. Mycopathologia, 157(1), 37-41. https://www.ncbi.nlm.nih.gov/pubmed/15008343. 